\title{
Vulnerability, resilience and adaptation of societies during major extreme storms during the Little Ice Age
}

\author{
Emmanuelle Athimon $^{1,2}$ and Mohamed Maanan ${ }^{1}$ \\ ${ }^{1}$ Université de Nantes, LETG-Nantes (UMR 6554), BP 81227 - 44312 Nantes CEDEX 3, France \\ ${ }^{2}$ Université de Nantes, CRHIA (EA 1163), 44312 Nantes CEDEX 3, France
}

Correspondence: Emmanuelle Athimon (emmanuelle.athimon@univ-nantes.fr) and Mohamed Maanan (mohamed.maanan@univ-nantes.fr)

Received: 25 May 2018 - Discussion started: 20 June 2018

Revised: 24 September 2018 - Accepted: 8 October 2018 - Published: 19 October 2018

\begin{abstract}
This paper reviews more than 19691 French historical documents from 14 French archive centres. To assess data from historical documents, a method has been applied that leads to a record of 101 extreme storms with damage, including 38 coastal floods. Thus, the results show periods of increasing and decreasing storm frequency. These periods are examined. Furthermore, coastal hazards have forced societies to adapt and develop specific skills, lifestyles and coping strategies. This paper analyses some responses of past societies to these hazards. By doing so, useful ideas may be (re)discovered by today's communities in order to enable us to adapt and develop resilience. Similarly, a thorough knowledge of past meteorological hazards may allow our societies to recreate a link with territory, particularly through the (re)construction of an effective memory of these phenomena.
\end{abstract}

\section{Introduction}

Climate change alters the occurrence and severity of extreme events. The frequency of these extreme events and their impact on humans calls for a more integrated risk management. Recent IPCC reports (IPCC, 2014) have shown that climate change will lead to increased risks and intensity of natural hazards, particularly droughts, heavy rains and river floods - for the moment, there is no consensus regarding the increase in storm frequency due to climate change. Over the past 15 years, at least three extreme storms (causing marine flooding, major impacts and deaths; Lothar and Martin, 1999); Klaus, 2009; and Xynthia, 2010) occurred on the French Atlantic coast. These events have exposed the neces- sity to create an efficient historical reconstruction and analysis of past storms over a long period in France (Garnier and Surville, 2011; Sarrazin, 2012; Athimon et al., 2016).

In the 14th-18th centuries, a storm is mentioned in historical documents if its impacts are major, meaning if it disrupts the manorial levy, induces extraordinary expenses, compromises salt or agricultural productions, puts a population in a traumatic situation that allows them a tax exemption for example. Although very precise and detailed damage descriptions are rare for the period, texts usually focus on consequences of extreme climatic hazards on the environment, societies and their activities (Barriendos and Martin-Vide, 1998; Athimon et al., 2016). This paper studies the human, material, agricultural, environmental and economic impacts of storms and tries to comprehend the vulnerability of past societies. In fact, while studying the socioeconomic parameters of impacts in a quantitative way, it is possible to measure a societies vulnerability (Bradzil et al., 2005, 2010; Pfister and Bradzil, 2006); albeit, for the early Little Ice Age (LIA; 14th-16th century), this is difficult to achieve. Furthermore, through cultural history, many researchers in historical climatology have recently focused on climate and extreme meteorological hazard representations, including people's attitudes and reactions (Pfister, 2010; Gerrard and Petley, 2013). As defining vulnerability of late medieval and modern societies is not the point of this paper, we will not discuss it. We will only admit that the concept of vulnerability indicates both the impacts of meteorological hazards on populations and the societies' ability to anticipate, mitigate and adapt (Fussel, Klein, 2006). 


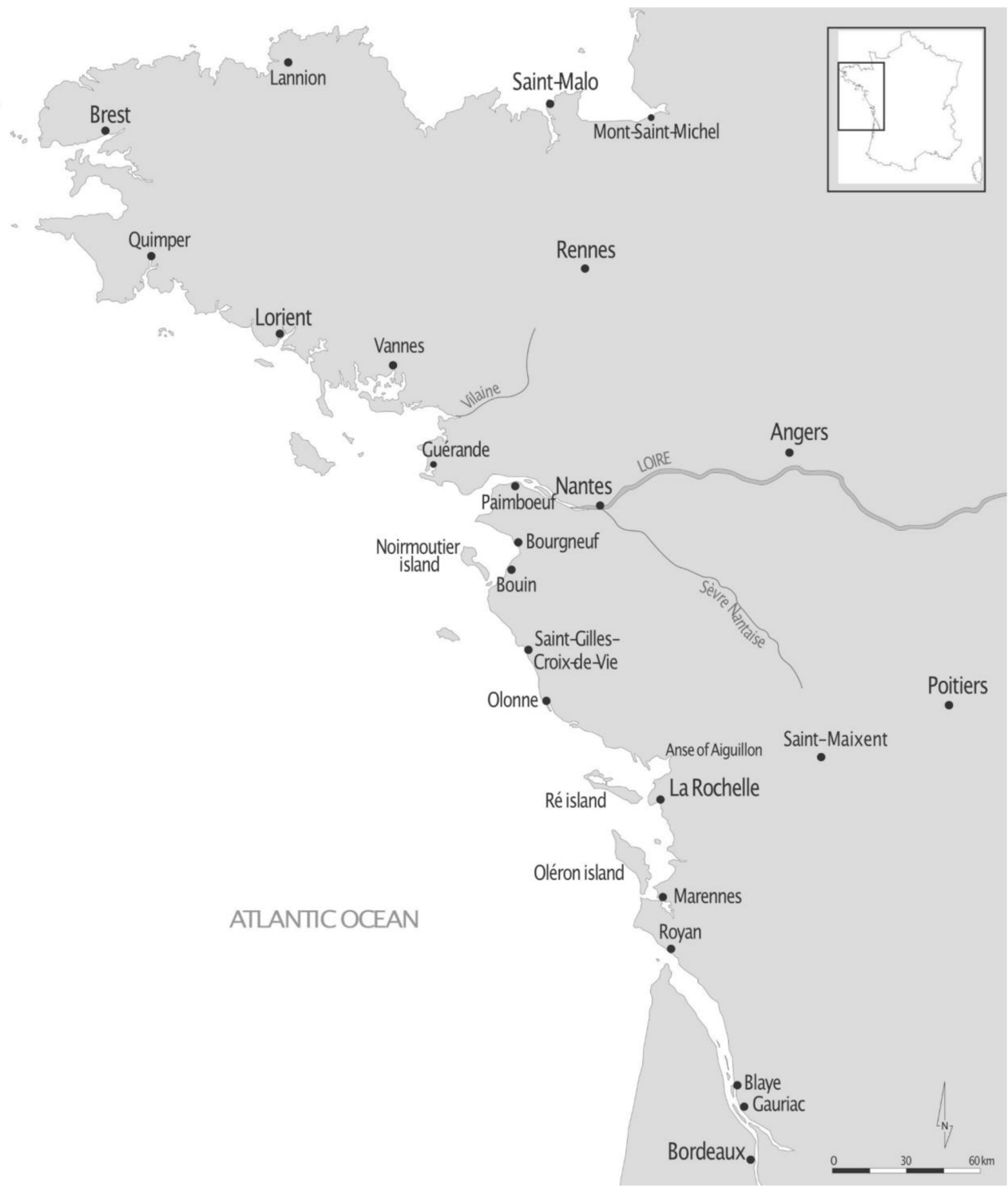

Figure 1. Map of the study area.

The LIA starts at the very beginning of the 14th (around 1300) and ends in the middle of the 19th century (around 1850) (Le Roy Ladurie, 1967; Lamb and Frydendahl, 1991; Pfister, 1996). Due to the rupture of the French Revolution in terms of environmental perceptions, societies' adaptation and mentalities (Richefort, 1999; Corbin, 1999), this study ends at the end of the 18th century (around 1790-1800). The LIA is known as a cooler period that has resulted in a glacial thrust (especially in the Alps), colder summers, regular floods and poor harvests causing episodic famine (Le Roy Ladurie, 2004, 2006). A wide body of research has proved that during the LIA there was an increased frequency of storms (Brooks, 1949; Gottschalk, 1971-1977; Lamb, 1980 and 1985; Hickey, 1997; Galloway, 2009) and, more recently, based on the number of proxies, Trouet et al. (2009) provide new evidence for enhanced storminess in northwest Europe during the LIA. Similarly, Vide and Cantos (2001) in Clima y Tiempos de España note four periods of catastrophic events (mid-15th century, 1570-1610, 1769-1800 and 1820-1860) marked by heavy rains, snowfalls and sea storms. Moreover, in western Europe, extreme storms can be devastating. In the North Sea, the sea floods of the Danish, English, Dutch and German coasts in 1421 and 1446 killed more than 100000 each in England and the Netherlands, while those of the year 1570 caused over 400000 deaths (Lamb, 1991, p. 174).

This paper is aimed at helping communities adapt to climate change by outlining a set of lessons derived from coastal hazards together with insights from contemporary and modern scholarship. These lessons are framed in the context of building resilient and sustainable communities in 
this era of climate change. This step will be followed by the development of a database on extreme events over the past 1000 years, to assess the impact of past climate changes on changes in the frequency and intensity of these events.

From historical examples of storms during the LIA, this research will

1. identify, as accurately as possible, the storms and coastal floods on the French Atlantic coast,

2. discuss the impacts of these phenomena on populations and

3. define the vulnerability, resilience and adaptation of French medieval and modern societies by presenting their perceptions and their reactions.

The geographic framework of this study is located in France, from Brittany to Gascony (Fig. 1), while the period of study stretches from the 14th to the 18th century. The study area includes rocky and sandy coasts, lowlands and marshes, and islands. This area is regularly affected by violent winds and episodic coastal flooding (Feuillet et al., 2012; Sarrazin, 2012; Garnier et al., 2018; Pouzet et al., 2018a, b).

\section{Materials and methods}

This research is based on French historical published and unpublished documents including narrative sources (chronicles, diaries and memoirs), archives (records of city repairs, books of accounts, parish registers and surveys conducted after a disaster, etc.) and ancient maps. In all, 19691 documents were consulted within the archive centres of the 14 French cities of Nantes, Angers, Saumur, Le Mans, Laval, Rennes, Vannes, Brest, Quimper, Saint-Brieuc, La Roche-sur-Yon, La Rochelle, Bordeaux and Paris. These historical documents contain observational and descriptive data on past storms, their impacts on societies, and the reactions and adaptation to them, allowing the study of past societies' vulnerability. Every historical source used for the redaction of this paper, including those already studied and published by other scientists, have been consulted. They have all been analysed and criticized.

The critical approach of sources is crucial. The redaction conditions of a document are essential to consider, as is the author and the institutional framework. No descriptive meteorological data are objective. Depending on the writer's age, their social environment, their life experiences, memories, perception of phenomenon, their propensity to exaggerate etc., the event's description will change. It is also necessary to define if the document is contemporary and if the author witnessed the related events (Hickey, 1997). If not, it needs to be determined whether the events occurred during the life-time of the author or if he copied it from other documents. In the case of a copy, the original manuscript (if it still exists) needs to be consulted to make comparisons and eventually correct any errors, mostly of date, in the transcription. Particular attention should be paid to dates (Bràzdil et al., 2005). In the west of France during the 14th-16th centuries, Easter style dates predominated. Therefore, the new year started at Easter. Here, dates have been homogenized in order to appear in the "new style" (n.st.). In other words, the " new " year is meant, even when the event happens in February. Moreover, in 1582, Pope Gregory XIII created the Gregorian calendar. This replaced the Julian calendar, which was then counting 10 days less (of late on the sun). In this present paper, before 1582, dates will be given both in the Julian and Gregorian calendars, the Gregorian dates being in parentheses. The correction of Julian dates is possible by adding 8 days to the 14th century dates, 9 days to those of the 15th century and 10 days to the 16th century dates. The possibility of improper understanding and interpretation of sources and data by the researcher should finally be admitted (Bràzdil et al., 2005).

According to Le Roy Ladurie (1967), to reduce the risk of improper interpretation and to use data contained in historical records for the study of climatic events and effects, four conditions must be satisfied: (1) the series must be annual; (2) they must be continuous, so without documentary gaps; (3) homogenous and (4) quantifiable. In matters of historical reconstruction of storms in the LIA, this methodology cannot exactly be followed. However, the important difference of the quality of documentary sources necessitates making a selection of data. This research is based on a strict critical approach of sources as discussed earlier and on precise criteria to generate data that is as reliable, coherent and relevant as possible (Barriendos and Martin-Vide, 1998). For this research, the identification and authentication of a storm relies on four criteria

1. The information comes from an eyewitness or a contemporary of the event ${ }^{1}$. However, the data are taken into account only if other first-hand sources and/or bibliographical documents confirm the reliability of the information.

2. The event is presented in the historical records as a storm and not, for example, as strong winds or a thunderstorm with high winds.

3. The date, as accurate as possible, is recorded, either because it is specified on the original document or it is possible to estimate it.

4. There is a description of the damage caused.

Once these four criteria are fulfilled, information is scrupulously analysed, criticized and included in databases to produce crosschecking. The crosschecking and comparison of

\footnotetext{
${ }^{1}$ Intellectuals, clergymen, people with municipal responsibilities, etc., with a good level of education and culture, produced the original documents. So, the information tends to be reliable, though sometimes exaggerated.
} 


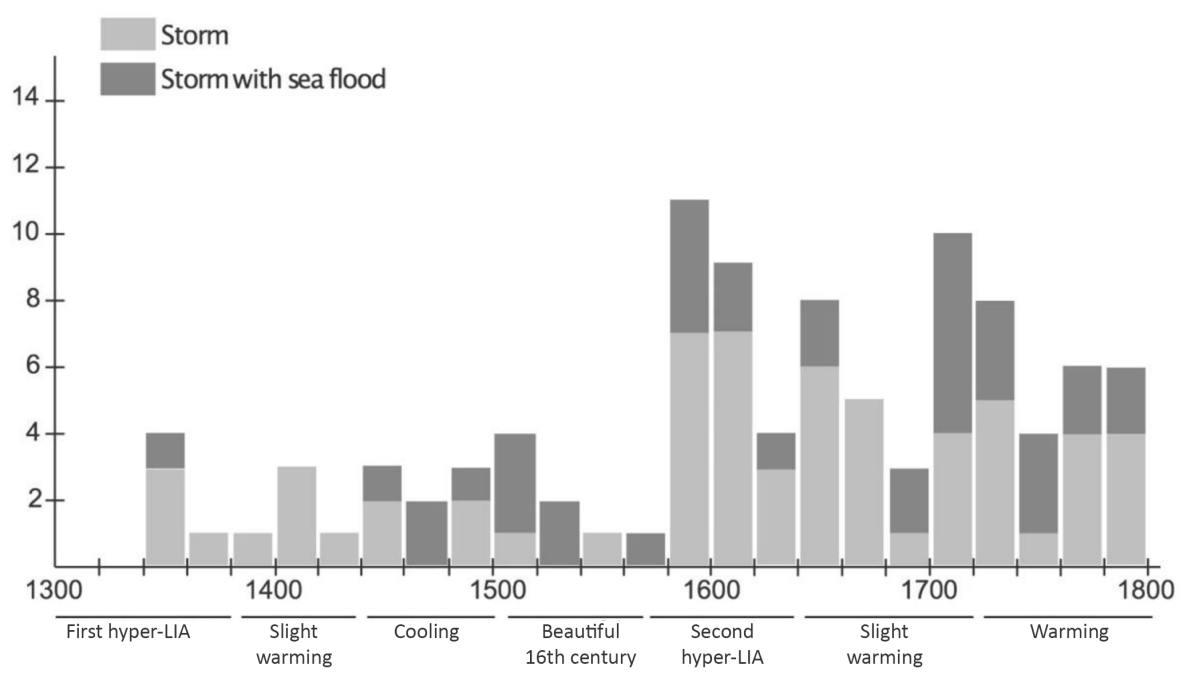

Figure 2. Number of storms and storms with sea floods in the study area.

data from different documentary sources allows for the historical reconstruction of storms within a defined temporal and spatial frame.

Fundamentally, the process of reconstruction is nevertheless difficult: some limits to the storm reconstruction work must be taken into account and discussed. First, as explained in the results section below, storms recorded in historical documents are ones with major impacts, even if climatologically speaking these are not necessarily the most violent events. It is therefore obvious that for many of these hazards, the historical climatologist has no information and even no clue they happened. In these circumstances, the reconstruction is somewhat biased. Secondly, the series of storms recorded in the west of France are discontinuous owing both to an oral tradition (Sarrazin, 2012) and many documentary gaps (Athimon, 2017). They are due to historical contingencies such as archival disasters ${ }^{2}$, the French Revolution ${ }^{3}$, wars such as the Hundred Years' War against England in the 14th-15th centuries, the religious wars between Protestants and Catholics in the 16th century, the Second World War etc. The loss of these documents certainly deprives the searcher of precious censuses of wind hazards. These first two limitations make any reliable appreciation of the recurrence of storms difficult. Moreover, today's satellite images allow precise delineation of the wind direction, the trajectory of a storm and the flooded areas, during medieval times a pre-

\footnotetext{
${ }^{2}$ For instance, the Chamber of Accounts fire in Paris in 1737 and the fire at the municipal Archives of Bordeaux Métropole in 1862 have caused the destruction of entire sets of registers, bundles and acts.

${ }^{3}$ Almost all of the documents relating to the life, history and possessions of some noble families, such as the Rohan and the La Trémoïlle families in Brittany, disappeared during the revolutionary episodes.
}

cise spatial demarcation is impossible to establish, mainly due to a lack of information, documentation and/or instruments. Finally, the descriptions are often either exaggerated or undervalued, which makes the characterization and the intensity estimations of a phenomenon difficult to undertake for the 14th-18th centuries.

Despite these limitations, through an acute critical study of documents, selection criteria of data and cross-checking, the historical climatologist can identify and characterize noteworthy storms and sea floods of the past.

\section{Results and discussion}

\subsection{Reconstruction of past storms}

With 19691 documents studied from the 14th to 18th century, this research is the most exhaustive work done on storms and storms causing coastal flooding during the LIA on the French Atlantic coast. A total of 138 storms were identified from the beginning of the 14th century to the end of the 18th century. However, due to the application of the strict criteria presented above, the final list of these phenomena is not as high in number and only 101 occurrences could be selected.

Figure 2 establishes a trend of increased and decreased storm activity. As can be seen, for instance, the late 16th century shows an intense stormy period. This period of cooling between 1560/70 and 1630/40 is well-known by historical climatologists and has been named the "Second Hyper LIA" (Lamb, 1980; Le Roy Ladurie, 2004). Similarly, the first 20 years and the end of the 18th century seem to stand out (Lamb and Frydendahl, 1991). These periods of increased frequency of storms also exist in the North Sea (Gottschalk, 1971, 1975, 1977; Lamb, 1980; Lamb and Frydendahl, 1991; De Kraker, 2013). However, the question of whether or not, and of the reasons why, some periods experienced more 


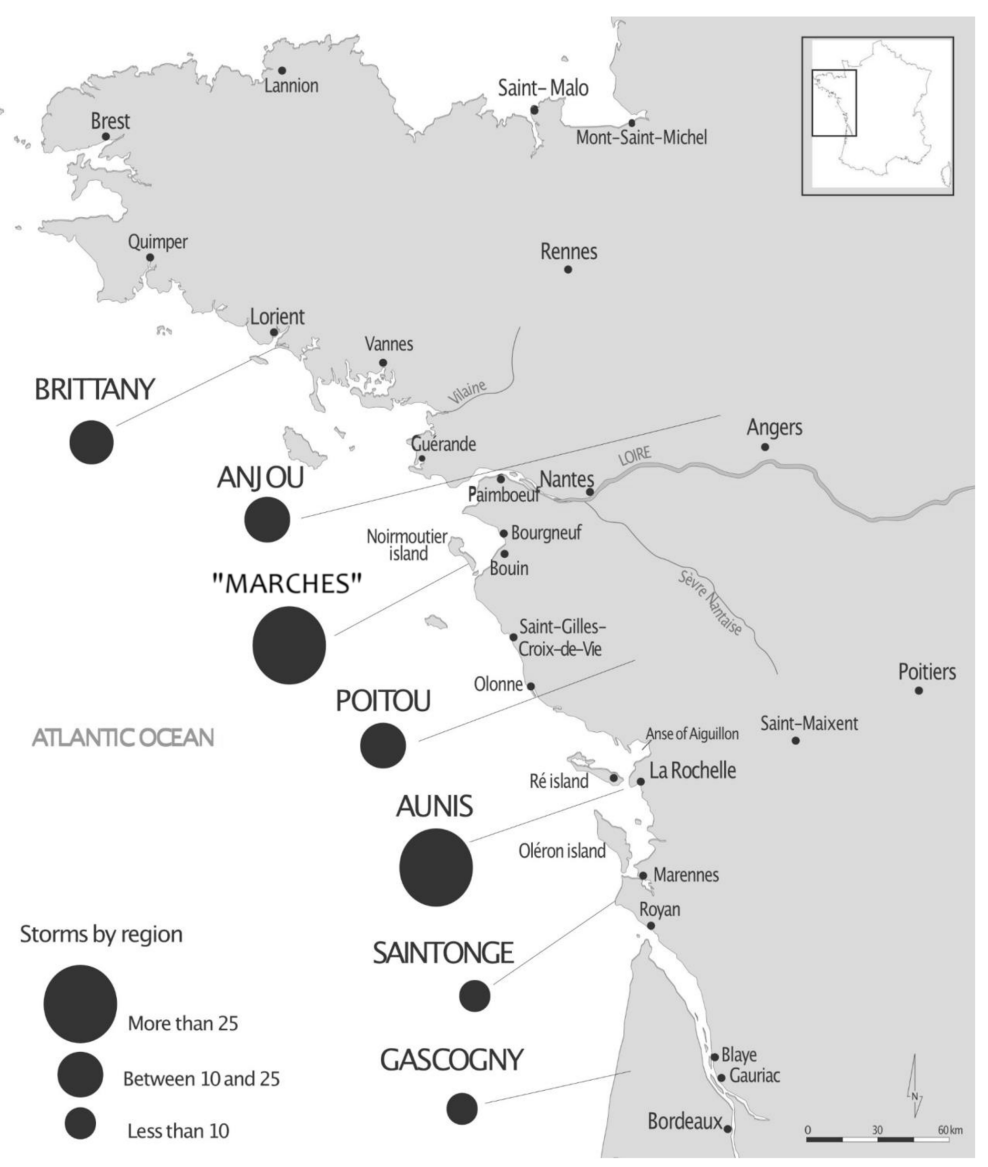

Figure 3. Map of areas subject to the risk of storms from 1300 to 1800.

storms than others is still discussed (Soens, 2018): is it due to temperature variation, the North Atlantic Oscillation (NAO). and/or interannual to multidecadal variability? An increase in human issues leading to more and more damage, so more and more historical records? A larger number of historical documents for some centuries? In fact, owing to the absence of documents, this figure is not exactly representative of the reality of the storms studied in the space-time frame, especially for the earlier periods. Furthermore, Aunis (particularly Ré island) and the area on the border of Brittany and Poitou called "Marches" (Bouin, Bourgneuf and Noirmoutier islands) are well represented (Fig. 3). This can be explained by extensive research on this spatial framework (Sarrazin, 2012; Athimon et al., 2016; Garnier et al., 2018): a natural vulnerability since these coastal areas are low lying, sandy and/or marshy (Pouzet et al., 2018a, b) and the presence of important human activities, such as salt production and agriculture that can be damaged by the winds and sea. Moreover, "Marches" is located at the junction of two storm lanes: one with west-east winds coming from Ireland and the UK, the second with southwest winds coming from the Bay of Biscay. Conversely, Brittany, which is subject to violent winds and located on the west-east wind trajectory, seems to not have been badly affected by past storms. This is mainly explained by the loss of a large number of archives during the wars and French Revolution mentioned previously.

Once they are identified, analysis of the storm descriptions allows for the study and definition of the impacts of storms on societies and their activities.

\subsection{Impacts and damage caused by storms}

Most of the damage was caused to monuments and buildings. Damage to infrastructure is globally demonstrated in a precise hierarchical structure. First are the religious monuments, whose alteration by wind disrupts populations. Second, the constructions where repair costs affect local finances are mentioned. The final cluster shows noble houses, while modest homes are often ignored (Garnier, 2010). For instance, a violent storm hit the French Atlantic coast on 24 June (3 July) 1452. It knocked down the bell towers of two churches in Angers (De Bourdigné, Chronique written in 1529) and washed away part of the roof of the La Tremoille 
family's castle on Noirmoutier island (AN ${ }^{4}$ Paris, 1 AP 1976, no. 176).

Storms can also lead to major damage to agriculture (damaged crops, seed dispersal, etc.). On 2 (12) July 1507 a storm occurred. One of the effects of the violent winds was the destruction of many wheat fields in Ancenis, Nantes and the surrounding areas (AD Loire-Atlantique, E 269, second book, fo. 8). In cases of significant agricultural damage, the manorial levy could be disrupted. For instance, in 1346, the sacristan of Bourg conducted an investigation in the parishes of Bayon and Gauriac in Gascogny. Farmers had difficulty paying taxes due to storm damage (AD Gironde, GG 236-II). Agricultural damage aside, a violent wind can also spoil the fauna and the flora: stranded fish, damaged trees and so on. From 29 December 1705 to 1 January 1706, there was a severe storm on the northwest French Atlantic coast. Brittany, and the countryside of Mayenne, Sarthe and Normandy, suffered extensively. During this storm, on the property owned by Saint-Melaine Abbey in Rennes, more than 120 trees were uprooted (Bordeaux, Journal d'un bourgeois de Rennes, 1598-1800, written by 5 eyewitnesses, 1992 edition), while in the parish of Montjean and that of Courbeveille, for example, more than 2000 fruit trees, chestnut and oak trees were uprooted (AD Mayenne, E dépôt 60/E13, view 6-7; E dépôt 116/E9, view 103).

This kind of extreme meteorological hazard can also endanger people's lives. Sources registering the number of dead as a result of a storm or a storm with sea flooding are rare. Descriptions mostly remain using words such as "several", "many" and "countless". From time to time, a source stands out and gives a number. It should nevertheless not be considered as the total number of deaths during the event since information is always localized. According to Etienne De Cruseau, at the end of March 1591 (end of February in reality), a west-southwest storm hit the French Atlantic coast. In Bordeaux, structural damage was so significant that at least four people died in their homes, while several were injured by falling roof tiles (De Cruseau, Chronique, written between 1587 and 1616, 1879-1881). Similarly, on 3 November 1656, during a violent storm which caused widespread damage on the Poitou, Brittany and the "Marches" coast, at least 184 people died in shipwrecks, such as the marshal of Meilleraye's warship (AM Nantes, GG 485, fo. 87).

During the medieval and modern periods, no overall or itemized records on the economic or human toll were provided after a climate event by the different institutions (urban, seigniorial or royal). This can be explained by the thinking of the day - the very notion of a human toll was unknown, because of the authorities' lack of organization, the poor administrative procedures and no other means were available. A general estimation of the economic and human cost of storms is therefore impractical. For a limited spatial framework such

\footnotetext{
${ }^{4} \mathrm{AN}$ : national archives; AD: departmental archives; AM: municipal archives.
}

as property, salt marshes, a fifedom, a town district, etc., accurate and reliable information on the amount of human (cf. supra), material or economic losses (or on the cost of repairs) can nevertheless be made available. Thus, in 1469 or $1470^{5}$, owing to flooding, the Blanchet family (modest notables) lost eight heaps of salt in the salt marshes of Bourgneuf and Prigny (AD Loire-Atlantique, 2 E 382), which is equivalent to the annual income of an average seigniory (Athimon et al., 2016). Sometimes information is not quantified, but the hazard is so extreme that several years of cleaning, restoration and repair are required. This kind of data thus gives interesting estimations of the loss generated by the event. During the winter of 1351-1352 (n.st.), a storm with coastal flooding overwhelmed some areas, in particular Noirmoutier island, for nearly half a century (AN Pierrefittesur-Seine, 1 AP 1974, no. 50) and destroyed salt marshes in Olonne (Cartulaire de l'abbaye de Saint-Jean d'Orbestier, 1877). Damage was so severe that almost 15 years later, in the middle of the 1360 's, salt production had still not been re-established (Mollat, 1983).

Where possible - depending on the data stored in historical documents - the study of past storms and their impacts must be followed by an analysis of societies' reactions and responses to these kinds of extreme meteorological hazards. The question of past societies' vulnerability, their adaptation and resilience is of huge importance. This appears to be the new focus of interest for historical climatologists (Pfister, 2010).

\subsection{Societies' reactions and responses}

Constantly living with the risk of storms and sea floods, coastal societies have developed significant risk awareness, an effective memory of these extreme meteorological hazards, a specific way of life, and a particular perception of natural hazards and risks. These elements are part of a mental coping strategy. They are of relevant importance in terms of societies' reactions to storms and sea floods as can be seen in Fig. 4. In fact, storms and sea floods were part of the culture and habits of past coastal societies, who were used to dealing with them and considered them a normal part of life. This is precisely what enabled them to have a fixed memory and develop specific knowledge of the events. The most destructive, traumatic or atypical storms and sea floods were preserved in their collective memory. The preservation and dissemination of these memories over a long period developed risk awareness among these old societies. In 1627, inhabitants in Bouin sent a petition to king Louis XIII in which they certified having suffered from more than 15 storms and coastal floods since the year 1500 (Luneau et Gallet, 1874, no. 33). Fur-

\footnotetext{
${ }^{5}$ The destruction of these salt heaps is either due to the storm with sea floods on 27-28 January (5-6 February) 1469 (n.st) or an unknown event which occurred between the end of the spring and the beginning of the summer of 1470 .
} 

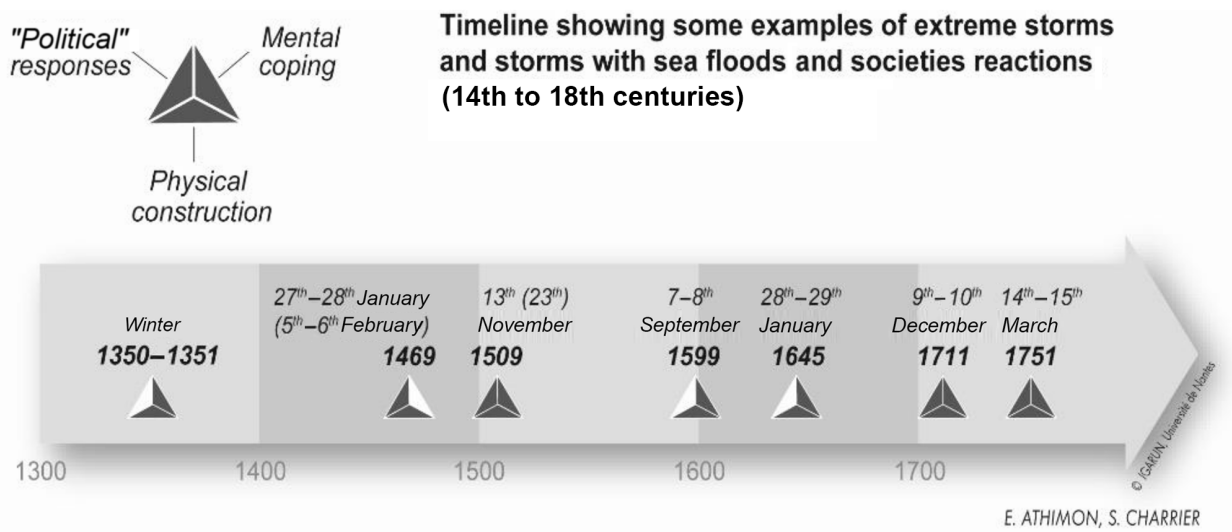

Figure 4. Major storms and the societies' reactions.

thermore, they wrote another memorandum dated 18 November 1775 in order to defend and explain their privileges in which they mention the storms and sea flooding which affected Bouin on 13 (23) November 1509 (Fig. 4), 31 December 1598, 7-8 September 1599 (Fig. 4), 14-15 March 1751 (AM Nantes, II 136, no. 30; Fig. 4). Memory is, however, not completely reliable since it is sometimes fragmentary and selective. This can result in exaggerations, anachronism, mental reconstructions, etc. It also relies on the author: their age, their discernment, and their understanding and interpretation of the events. (Athimon et al., 2016). A meteorological event can also seem more violent than an earlier identical one. Despite these limitations, memory of extreme meteorological hazards can continue over several decades, which results in promoting risk awareness, develops adaptability and resilience and a better understanding of the elements. A better understanding and interpretation of the elements is of significant importance. Unlike today, older coastal societies considered the sea a constant and unpredictable threat. In 1451, a memorandum, sent to the court of King Charles VII, sets forth the feelings of coastal societies and its dangers (Mémoires présentés au roi Charles VII par les délégués de la ville de Poitiers pour le détourner d'établir la gabelle en Poitou et en Saintonge, 1873). This document rests on an old, but reliable, hazards observation practice and a perpetual struggle with limited resources against the sea and its risks. In the 14th-18th centuries, risks and storm hazards were incorporated into memory, culture, habits and the lifestyle of coastal societies. This contributed to the development of specific knowledge, risk awareness and prevention measures.

During the studied period, dikes are built in order to provide sea defences against swell, chop and tidal movements, and reclaim land from the sea (Thoen et al., 2013). They also protect salt marshes, fields, infrastructure and local populations from coastal flooding. They are part of coastal management by societies in order to deal with storms and sea floods, as can be shown in Fig. 4. They are small, around $2 \mathrm{~m}$ high, and made up of clods of clay, sand, wood and pebbles (Sar- razin, 2014). Leaky and fragile, they are easily destroyed but are useful coastal defences. Moreover, their structure makes them very easy and quick to repair. Unlike the Netherlands (Soens, 2009) or England (Galloway, 2009), on the French Atlantic coast no real authority interferes in dike construction (Sarrazin, 2014). Dike construction and maintenance relies either on owners of lands and salt marshes or, if they are public, on the community (Sarrazin, 2014). In 1492-1493 (n.st.), some dikes broke due to sea and wave pressure on the island of Noirmoutier. Their restoration cost was modest for lord La Trémoïlle, owner of these dikes (AN Pierrefittesur-Seine, 1 AP 1964). These low costs are mostly due to the abundance of cheap labour. However, sometimes the cost is exorbitant. For example, in a document dating from the 7 December 1663, David Tessier and his wife, Janne Jumel inhabitants of Croisic, near Guérande, state that they had to restore their marsh dikes following a violent storm on 1213 January 1663. These repairs cost more than 6000 livres (AD L-A., B 655, fo. 277)!

The vulnerability management of past coastal societies is mainly based on a precise social and work organization. Everyone (lords, farmers, fishermen, salt producers, etc.) had a specific role to play. Everyone's involvement in the construction or repair of dikes and territory management develops risk awareness and ensures its dissemination within the society (Sarrazin, 2014). The risks are then perfectly integrated into the coastal societies' conception and lifestyle (Galloway and Potts, 2007). Therefore, the vulnerability of coastal societies, in particular salt producing ones, is scaled down. Furthermore, during the late Middle Ages and modern period, dikes are built in a subdivision system. In other words, it is an intricate network of levees. Next to Anse de l'Aiguillon, a map of Champagné swamps drawn by André Chevreux in 1656 (AD Vendée, $1 \mathrm{E} 442$ ) presents this spatial subdivision. Dikes follow each other in a quasi-"sequential" order: the newest are erected on the seafront, while the older ones are further back. This technique is part of a preventive approach (Athimon et al., 2016). When the sea floods, it en- 


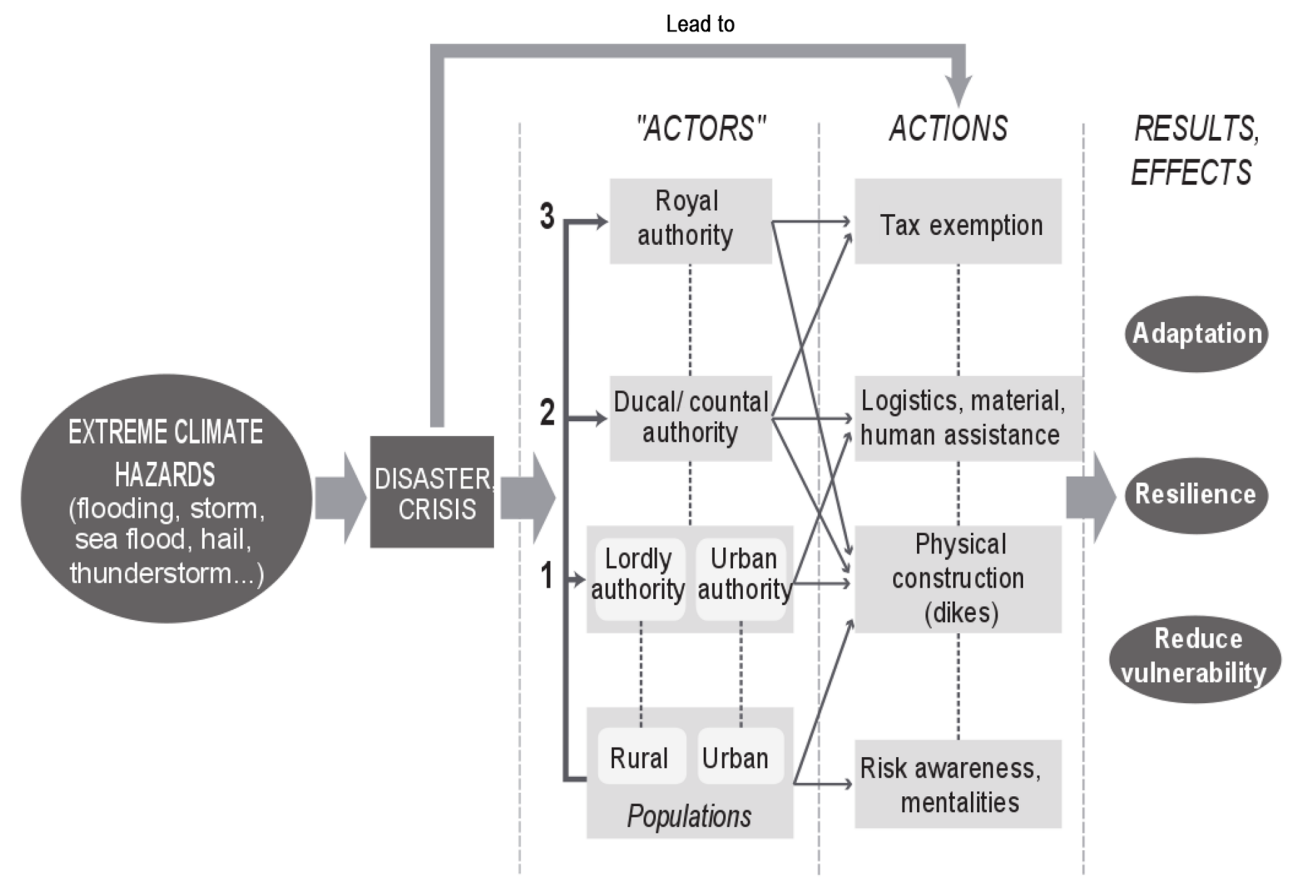

Figure 5. Simplified representation of governance and disaster management.

counters a multitude of small levees which absorb the wave energy and break the speed of waves, lessen the intensity of flooding and reduce the spread of the water. In fact, populations were aware of the importance in maintaining levees, including the older ones, as noted in a Champagné seigniorial court document of the 7 November 1560 (Médiathèque de Niort, fonds La Fontenelle de Vaudoré - Clouzot, 1904; Sarrazin, 2014). Finally, the construction, development, maintenance and repair of dikes are part of the lifestyle and the culture of coastal societies. They are also connected to a notion of anticipation of future damage and risk prevention (Athimon et al., 2016).

It was not until the late 18th century that the royal authority becomes a systematic reference in the case of an extreme hazard (Favier, 2002). However, at the end of the Middle Ages and during the whole modern period, French kingdom authorities' interference gradually increases (Athimon et al., 2016). A range of societies' reactions and responses to meteorological disaster are seen in Figs. 4 and 5. Figure 5 shows that the first to react to a disaster is the local population followed by the local authorities, either seigniorial or urban. Next, the counts, dukes and princes can offer their assistance. The king appears as the last resort. Each "player" offers different reactions which result in three main effects: adaptation, resilience and a reduction in vulnerability (Fig. 5). In the case of local authority intervention, actions were mainly practical: materials, labour, funding and supervision in order to rebuild and repair. Through court proceedings, local authorities could also compel people to repair damaged sites. This is what happened after the violent storm with sea flooding on 22 August (1 September) 1537 at Ré island: people who did not take part in the cleaning, restoration and repair of flooded areas or public levees could incur very heavy fines (AN Pierrefitte-sur-Seine, 1 AP 2002). In addition, ducal and royal institutions could also intervence. Their reactions are mostly financial: they provide tax assistance. In 1392, King Charles VI gives a tax exempttion to the inhabitants of Noirmoutier island who fought to prevent the English from landing on the island and regularly experience storms and sea floods (Recueil des documents concernant le Poitou contenus dans les registres de la Chancellerie de France, 1893). Moreover, the royal authority gradually intermediates on the construction, maintenance and repair of dikes. For instance, on 9 February 1510 (n.st.) - after the stormy winter of 1509-1510 (n.st.) and the sea flooding of 13 (23) November 1509 - the duke of Brittany, also King of France, Louis XII sends a letter to his alderman in Nantes to coerce him to visit the disaster areas (AD Loire-Atlantique, B 20, view 34 scan). The aim is to keep abreast of the situation, have an idea of the amount of damage and see if repairs are needed. The damage is so significant that on the 23 June 1511, the duchess of Brittany, also Queen of France, Anne, orders a 5-year tax exemption to the disaster victims (Luneau and Gallet, 1874). Extreme meteorological hazards such as storms and sea floods have led the various authorities in the kingdom of France to take decisive action. Their point was somehow to provide post-disaster support and prevent future risks. 


\section{Conclusions}

Historical documents can contain data on weather disasters, so research into historical climatology can identify past storms over time and the impact of these phenomena on populations and responses, adaptability and resilience of older societies. This paper shows periods of increasing and declining storm frequency during the LIA on the French Atlantic coast. These periods, such as that of 1560/70-1630/40, can be cross-checked with those of the North Sea, but also other hazards such as heavy rains and river floods in Europe (Vide and Cantos, 2001; Macdonald and Sangster, 2017). Future research should deeply question relations between these periods and temperatures, NAO, and multidecadal variability. In addition, this paper shows evidence of storm impacts on populations and of the seniority of societal' reactions to mitigate storms and sea floods. Nowadays, as in the past, storms have material, structural and functional impacts on the economy, activities (agricultural, salt production, etc.) and people. Used to cope with storms, 14th-18th century populations had developed specific practices that allowed them to adapt, stay aware of risks and incorporate them into their lifestyle, such as a long-term memory of past events, a good understanding of the danger of natural elements or a "sequential" order of dikes. These practices led to the reduction of their vulnerability.

By providing information about past extreme meteorological hazards, this field and paper are of the utmost importance for the current concerns and discussions about climate change, increasing vulnerability and risks, and greater severity of hazards. Indeed, by providing a thorough knowledge of past storms and coastal flooding, this paper allows today's societies to (1) recreate a link with their territory, (2) develop an effective memory of these events and (3) develop new strategies based on the experiences of older societies. This paper (and historical research in general) can make a relevant contribution to prevention and management of natural risks and hazards.

Future work will take into account a greater quantity and a wider range of sources in order to improve the knowledge and reconstruction of past storms. They will be extended over a longer historical period in order to try to calculate the frequency of storms and coastal floods. Another objective is to identify the periods of increased and decreased storm activity over the last 700 years and correlate them with climatic fluctuations (Lamb, 1980). This may also enable us to identify modifications in attitudes and lifestyles, some changes in risk perception, loss of habits, technical development, and their connections to adaptability, resilience and vulnerability. By analysing the responses of past societies to extreme weather hazards, useful strategies may be (re)discovered in order enable us to innovate, adapt and develop resilience in today's societies. In collaboration with French researchers, some correlations will also be made with coastal sediment. Finally, with the aim of identifying trajectories, storm corri- dors etc., international collaboration will be required; including co-operation with sociologists, psychologists, anthropologists, etc., which will be of great interest to investigate and better understand the social perceptions and representations of past extreme climate and meteorological hazards (Brazdil et al., 2005).

Data availability. Data are publicly accessible from the archive centres that are referenced in the text and in the references section. They are linked to $\mathrm{PhD}$ research. The thesis defense is scheduled for March 2019.

Author contributions. AE did the investigation and she analysed data. AE prepared and conceptualized the paper with contributions from MM. MM supervised researches and managed the research projects and financial support.

Competing interests. The authors declare that they have no conflict of interest.

Acknowledgements. The Fondation de France (contract number 1503 ) and OR2C-AXIS 3 (part of the OSUNA programme and the Pays-de-la-Loire region) funded analysis, operating costs and field measurements.

Edited by: Chantal Camenisch

Reviewed by: Herve Regnauld and Abdelmounim El M'rini

\section{References}

Athimon, E., Maanan, M., Sauzeau, Th., and Sarrazin J.-L.: Vulnérabilité et adaptation des sociétés littorales aux aléas météomarins entre Guérande et l'île de Ré, France (XIV $-\mathrm{XVIII}^{\mathrm{e}}$ siècles), Vertigo, 16, https://doi.org/10.4000/vertigo.17927, 2016.

Bailey M.: Per impetum maris: natural disaster and economic decline in eastern England, 1275-1350, in: Before the Black Death, Studies in the "crisis" of the early fourteenth century, edited by: Campbell, B., Manchester-New-York, 184-208, 1991.

Barriendos Vallve, M. and Martin-Vide, J.: Secular climatic oscillations as indicated by catastrophic floods in the Spanish Mediterranean coastal area (14th-19th centuries), Climatic Change, 38, 473-491, 1998.

Bordeaux, Cl:: Moi, Claude Bordeaux: journal d'un bourgeois de Rennes au $17^{\mathrm{e}}$ siècle, published by: Isbled B., éd. Apogée, Rennes, 1992.

Bowden K. F.: Storm surges in the North Sea, Weather, 8, 82-84, 1953.

Brazdil, R., Pfister, Ch., Wanner, H., Von Storch, H., and Luterbacher J.: Historical climatology in Europe - The state of the art, Climatic Change, 70, 363-430, 2005.

Bradzil, R., Dobrovolny, P., Luterbacher, J., Moberg, A., Pfister, Ch., Wheeler, D., and Zorita, E.: European climate of the past 
500 years: new challenges for historical climatology, Climatic Change, 101, 7-40, 2010.

Britton, C. E.: A meteorological chronology to A.D. 1450, Geophysical Memoirs, 70, London, H. M. S. O., 177 pp., 1937.

Brooks, C. E. P.: Climate through the ages: A study of the climatic factors and their variation, 2nd Edn., Dover Publications, New York, 1949.

Carey, M.: Climate and history: a critical review of historical climatology and climate change historiography, WIREs Climate Change, 3, 233-249, 2012.

Cartulaire de l'abbaye d'Orbestier: Archives Historiques du Poitou, edited by: de La Boutetiere, L., t. VI, Poitiers, no. 194, 1877.

Clouzot, E.: Les marais de la Sèvre niortaise et du Lay du $\mathrm{X}^{\mathrm{e}}$ à la fin du $\mathrm{XVI}^{\mathrm{e}}$ siècle, Paris-Niort, pièce no. XVIII, Médiathèque de Niort, fonds de La Fontenelle de Vaudoré, carton 144, no. 4, 237-240, 1904.

Corbin, A.: La mer et l'émergence du désir du rivage, in Les sources de l'histoire de l'environnement. Le XIX ${ }^{\mathrm{e}}$ siècle, Corvol, A.(dir.), L'Harmattan, Paris, 31-38, 1999.

De Bourdigné, J.: Hystoire agregative des Annalles et cronicques Daniou, edited by: Galliot du Pré, Paris, 1529.

De Cruseau, E.: Chronique, published by: Société des bibliophiles de Guyenne, t. 1 and 2, Bordeaux, 1879-1881.

De Kraker, A.: Storminess in the Low Countries, 1390-1725, Environ Hist-UK, 19, 149-171, 2013.

Departemental Archives of Gironde: G 236-II.

Departemental Archives of Loire-Atlantique: B 20, view 34 (scan), B 655, fo. 277, E 269, second book, fo. 8, 2 E 382, fo. 4.

Departemental Archives of Mayenne: E dépôt 60/E13, view 6-7 (scan), E dépôt 116/E9, view 103 (scan).

Departemental Archives of Vendée: 1 E 442.

Favier, R.: Les pouvoirs publics face aux risques naturels dans l'histoire, CNRS-MSH Alpes, Grenoble, 444 pp., 2002.

Feuillet, T., Chauveau, É., and Pourinet, L.: Xynthia est-elle exceptionnelle?? Réflexions sur l'évolution et les temps de retour des tempêtes, des marées de tempête, et des risques de surcotes associés sur la façade atlantique française, Norois, 222, 27-44, 2012.

Fussel, H.-M. and Klein, R. J. T.: Climate change vulnerability assessments: an evolution of conceptual thinking, Climatic Change, 75, 301-329, 2006.

Galloway, J. A.: Storm flooding, coastal defence and land use around the Thames estuary and tidal river c. 1250-1450, J. Medieval Hist., 35, 171-188, 2009.

Galloway, J. A. and Potts, J. S.: Marine flooding in the Thames Estuary and tidal river c. 1250-1450: impact and response, Area, 39, 370-379, 2007.

Garnier, E.: Les dérangements du temps. 500 ans de chaud et de froid en Europe, Plon, Paris, 244 pp., 2010.

Garnier, E. and Surville, F.: La tempête Xynthia face à l'histoire ; submersions et tsunamis sur les littoraux français du Moyen Âge à nos jours, Le Croît Vif, Saintes, 176 pp., 2011.

Garnier, E., Ciavola, P., Spencer, T., Ferreira, O., Armaroli, C., and McIvor, A.: Historical analysis of storm events: case studies in France, England, Portugal and Italy, Coast Eng., 134, 10-23, 2018.

Gerrard, C. and Petley, D.: A risk society? Environmental hazards, risk and resilience in the later Middle Ages in Europe, Nat. Hazards, 69, 1051-1070, 2013.
Gottschalk, M. K. E.: Stormvloeden en riveroverstromingen in Nederland, 3 volumes, Van Gorcum, Assen, 1971, 1975, 1977.

Hickey, K. R.: Documentary records of coastal storms in Scotland, 1500-1991 A.D., 2 volumes, Thesis, Coventry University, Coventry, 1997.

IPCC: Climate Change 2014, Synthesis report, Contribution of Working Groups I, II and III to the Fifth Assessment Report of the intergovernmental Panel on Climate Change, edited by: Core Writing Team, Pachauri, R. K., and Meyer, L. A., IPCC, Geneva, 151 pp., 2014.

Lamb, H. H.: Climatic fluctuations in historical times and their connections with transgressions of the sea, storm floods and other coastal changes, in: Transgressies and Occupatiegeschiedenisn de kustgebieden van Nederland en Belgie, edited by: Verhulst, A. and Gottschalk, M. K .E., Belgisch Centron Voor Landelifke Greschiedenis, Gand, 251-281, 1980.

Lamb, H. H.: The Little Ice Age period and the great storms within it, in: The Climatic Scene, edited by: Tooley, M. J. and Sheail G. M., London, Allen and Unwin, 104-131, 1985.

Lamb, H. H. and Frydendahl, K.: Historic storms of the North Sea. British Isles and Northwest Europe, Cambridge University Press, Cambridge, 204 pp., 1991.

Le Roy Ladurie, E.: L'histoire du climat depuis l'an mil, Flammarion, Paris, 379 pp., 1967.

Le Roy Ladurie, E.: Histoire humaine et comparée du climat, 3 volumes, Fayard, Paris, 2004, 2006, 2009.

Luneau, S. and Gallet E.: Documents sur l'île de Bouin, Nantes, no. XIII and no. XXXIII, 1874.

Macdonald, N. and Sangster, H.: High-magnitude flooding across Britain since AD 1750, Hydrol. Earth Syst. Sci., 21, 1631-1650, https://doi.org/10.5194/hess-21-1631-2017, 2017.

Marchand, J.-P., Bonnardot, V., and Planchon, O.: Le climat de Laval au début de la Renaissance. Essai de géographie historique, Annales de Bretagne et des Pays de l'Ouest, 122, 103-133, 2015.

Marchand, J.-P., Planchon, O., and Bonnardot, V.: La variabilité des types de temps mensuels au XVIII ${ }^{\mathrm{e}}$ sièle à Laval: approche méthodologique, in: Climat et pollution de l'air, edited by: Fallot, J.-M., Joly, D., and Bernard, N., UNIL-UBFC, Lausanne, 315320, 2016.

Mémoires présentés au roi Charles VII par les délégués de la ville de Poitiers pour le détourner d'établir la gabelle en Poitou et en Saintonge, in: Archives Historiques du Poitou, tome II, Poitiers, 1873.

Mollat, M.: La vie quotidienne des gens de mer en Atlantique, $\mathrm{IX}^{\mathrm{e}}$ $\mathrm{XVI}^{\mathrm{e}}$ siècle, Hachette, Paris, 266 pp., 1983.

Municipal Archives of Nantes: GG 485, fo. 87, II 136, no. 30.

Municipal Library of Angers: Oudin G., Extrait d'un manuscrit de Messire Guillaume Oudin, prestre sacristin de l'abaye de Nostre Dame du Ronceray, depuis l'année 1447 jusqu'en l'an 1499, copy of the XVIth century, original lost, ms. 0976 (0858) (scan).

National Archives of Pierrefitte-sur-Seine: 1 AP 1964, 1 AP 1974 - MIC/1AP/1974, no. 50 (microfilm), 1 AP 1976 - MIC/1AP/1976, no. 174 (microfilm), 1 AP 2002 MIC/1AP/2002, no. 75 (microfilm).

Pfister, Ch.: The vulnerability of past societies to climatic variation: a new focus for historical climatology in the twenty-first century, Climatic Change, 100, 25-31, 2010.

Pfister, C. and Brázdil, R.: Social vulnerability to climate in the "Little Ice Age": an example from Central Europe in the early 
1770s, Clim. Past, 2, 115-129, https://doi.org/10.5194/cp-2-1152006, 2006.

Pfister, Ch., Wegmann, M., and Schwarz-Zanetti, G.: Winter severity in Europe: The fourteenth century, Climatic Change, 34, 91108, 1996.

Pouzet, P., Maanan, M., Piotrowska, N., Baltzer, A., Stephan, P., and Robin, M.: Chronology of Holocene storm events along the European Atlantic coast: New data from the Island of Yeu, France, Prog. Phys. Geog., 42, 431-450, doi.org/10.1177/0309133318776500, 2018a.

Pouzet, P., Robin, M., Decaulne, A., Gruchet, B., and Maanan M.: Sedimentological and dendrochronological indicators of coastal storm risk in western France, Ecol. Indic., 90, 401-415, 2018 b.

Recueil des documents concernant le Poitou contenus dans les registres de la Chancellerie de France, published by: Guérin, P., impr. Oudin, tome VI, Poitiers, no. DCCLXXIII, 88-92, 1893.

Richefort, I.: Nature et société : le sentiment d'une crise profonde, in: Les sources de l'histoire de l'environnement. Le XIX ${ }^{\mathrm{e}}$ siècle, edited by: Corvol, A., L'Harmattan, Paris, 111-118, 1999.
Sarrazin, J.-L.: "Vimers de mer" et sociétés littorales entre Loire et Gironde (XIV ${ }^{\mathrm{e}}-\mathrm{XVI}^{\mathrm{e}}$ siècle), Norois, 222, 91-102, 2012.

Sarrazin, J.-L.: Digues, bots et chaussées. Les levées de défense face à la mer dans les zones littorales basses de l'Europe du NordOuest $\left(\mathrm{XI}^{\mathrm{e}}-\mathrm{XVI}{ }^{\mathrm{e}}\right.$ siècle), in: S'adapter à la mer. L'homme, la mer et le littoral du Moyen Âge à nos jours, edited by: Laget, F. and Vrignon, A., PUR, Rennes, 47-70, 2014.

Soens, T.: Resilient societies, vulnerable people : coping with North Sea Floods before 1800, Past Present, 1-36, 2018.

Soens, T.: De spade in de dijk? Waterbeheer en rurale samenleving in de Vlaamse kustvlakte (1280-1580), Ginkgo Academia Press, Gand, 359 pp., 2009.

Thoen, E. and Borger, G. J. (Eds.): Landscapes or Seascapes? The History of the Coastal Environment in the North Sea Area Reconsidered, Brepols, Turnhout, 428 pp., 2013.

Trouet, V., Esper, J., Graham, N. E., Baker, N., Scourse, J. D., and Frank, D. C.: Persistent Positive North Atlantic Oscillation Mode Dominated the Medieval Climate Anomaly, Science, 324, 78-80, 2009.

Vide, J. M. and Cantos, J. O (Eds.): Climas y tiempos de España, Alianza Editorial, Spain, 2001. 